\title{
A comparison of economic and non-economic efficiency of private and public hospitals in the Czech Republic
}

\section{Pavla Staňková*}

Department of Management and Marketing, Faculty of Management and Economics,

Tomas Bata University in Zlín, Mostní 5139, 760-01 Zlín, Czech Republic

Email: stankova@utb.cz

*Corresponding author

\section{Šárka Papadaki}

Department of Enterprise Economics, Faculty of Management and Economics, Tomas Bata University in Zlín, Mostní 5139, 760-01 Zlín, Czech Republic Email: papadaki@utb.cz

\begin{abstract}
This article found the answer to the question whether the ownership is a factor influencing hospital effectiveness. One of the goals of the research was to compare the efficiency of private hospitals and public hospitals. The research was focused on all the 188 hospitals in the Czech Republic. There was a comparison of economic efficiency indicator (economic outcome) and comparison of non-economic efficiency indicators (bed usage in days and average duration of stay). For comparison of effectiveness of public and private hospitals, the two-sample t-test for equal means, the statistical program SPSS was used. Since the P-values are greater than the significance level (0.05), we cannot reject the null hypothesis for the following factors of effectiveness: economic outcome and bed usage in days. According to the research results, we can confirm that there are differences in effectiveness measured by indicator 'bed usage in days' between public and private hospitals.
\end{abstract}

Keywords: healthcare; hospital; effectiveness; public sector; private sector; economic outcome; bed usage; average duration of stay; Czech Republic; two-sample t-test.

Reference to this paper should be made as follows: Staňková, P. and Papadaki, Š . $x x x x)$ 'A comparison of economic and non-economic efficiency of private and public hospitals in the Czech Republic', Int. J. Public Sector Performance Management, Vol. X, No. Y, pp.xxx-xxx.

Biographical notes: Pavla Staňková is an Associate Professor and the Head of the Department of Management and Marketing of Faculty of Management and Economics, Tomas Bata University in Zlín. In her research work is engaged in an issue of healthcare marketing and healthcare effectiveness. She was a coordinator and solver of many project focused on healthcare sector. 
Š́arka Papadaki is an Assistant Professor of the Department of Enterprise Economics of Faculty of Management and Economics, Tomas Bata University in Zlín. In her research, she is engaged in an issue of healthcare and costs control in health organisations. She was a coordinator and solver of many project focused on healthcare sector.

\section{Introduction}

For many years and decades, European countries are confronted with a rise of expenses in health (Keramidas and Bout-Colonna, 2007). This is according to Herr et al. (2011), due to two main factors - technological progress and demographic change and each country tries to find the solution on this problem by a new system of management, trying to set up a powerful and efficient management of outflow (Keramidas and Bout-Colonna, 2007).

Hospitals represent a significant proportion of health expenditures. At present, hospitals in the Czech Republic use up to half of all costs (Institute of Health Information and Statistics of the Czech Republic, 2000-2013). That is why it is necessary to pay attention to the efficient use of hospital resources. Many authors are currently discussing this topic and the analysis of hospital efficiency has become an important issue in health economics literature. The importance of the efficiency measurement and its increase can be observed in the following example. A modelling exercise in Australia demonstrated that a $4 \%$ gain in the efficiency of hospitals would contribute to a $1.9 \%$ increase in the overall efficiency of the country's health system; this signifies the important role played by hospitals in influencing the overall health systems efficiency (National Health and Hospitals Reform Commission, 2009).

There are many ways to measure financial performance of organisations. For example, in other industries, we can use return of investment, but this is not the best indicator how to measure efficiency of private and public hospitals (Tiemann and Schreyögg, 2012).

This paper gives a comprehensive evaluation of hospital efficiency by focusing on the private and public sectors in the Czech Republic.

The main aim of this research was to determine if there is a difference in efficiency between the hospitals which are in the public ownership and those which are in the private ownership.

\subsection{Hospitals in the Czech Republic}

On 9 November 1989, when the Berlin Wall was torn down, began the changes in the healthcare sector in countries of the Communist Block. The situation in the Czech Republic was influenced by the political changes after 'velvet revolution' on 17 November 1989. The economy and public sector of the Czech Republic has experienced rapid change since 1991, with the fall of the Soviet Bloc and separation from Slovakia (see Dana, 2000, 2010 for details). This event formally marked the beginning of the transition process from administrative and command economies to market economies, from public to private ownership. This process included two parts of transitions: political and economic transitions. The political transition included political liberalisation, free 
elections and democratisation and the economic transition included economic liberalisation (where central administration of prices is replaced by market mechanisms, which involves better market opportunities as well as higher levels of competition), privatisation and the creation of market institutions (Dana and Ramadani, 2015).

The legal framework regarding the privatisation of the healthcare sector and private healthcare is defined by the Act No. 160/1992 Coll., which deals with medical care in private health facilities. The increase of the number of healthcare facilities in the Czech Republic in years 1992-2015 can be observed in Figure 1. This shows that the period of privatisation (after 1989) has led to a fast increase of the number of healthcare facilities. Most prominent is the leap from the total number of 3,956 facilities in 1992 to 17,176 facilities at the end of 1993 .

Figure 1 The increase of the number of healthcare facilities in the Czech Republic in years 1992-2015 (see online version for colours)

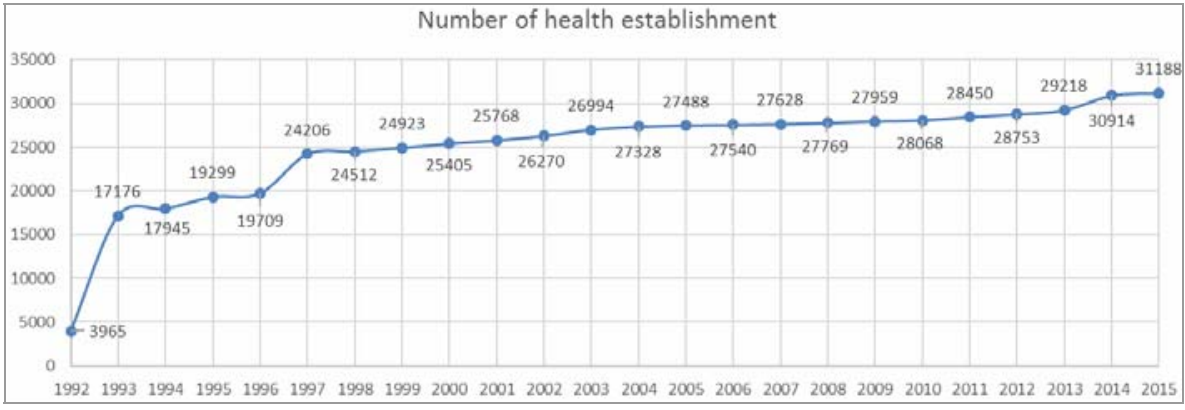

Source: Institute of Health Information and Statistics of the Czech Republic (2000-2013, 2015)

Figure 2 Number of hospitals in the Czech Republic from 1994 to 2015 (see online version for colours)

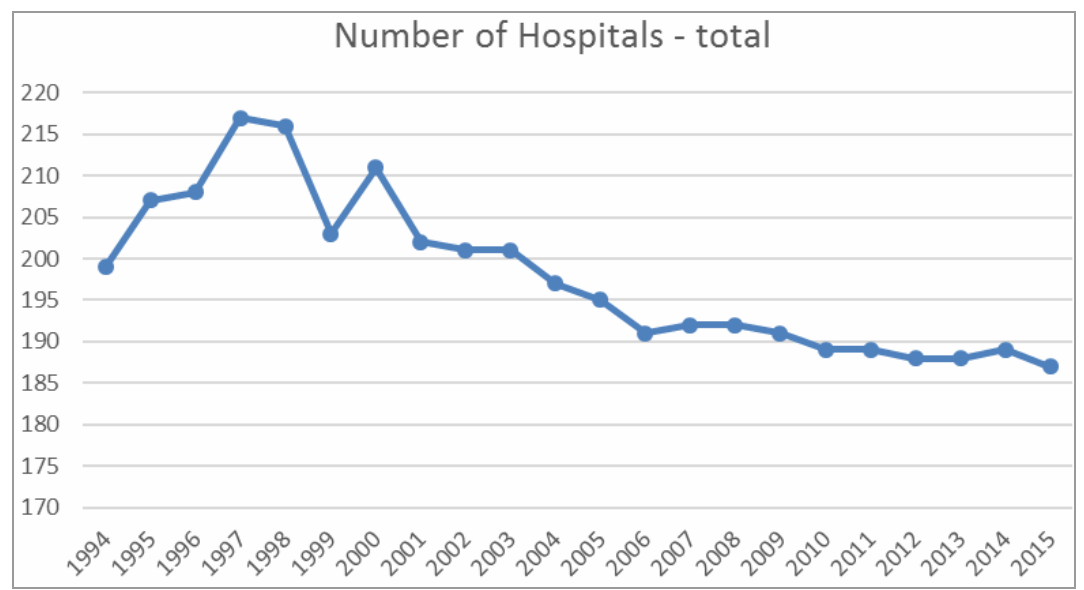

Source: Institute of Health Information and Statistics of the Czech Republic (2000-2013, 2015) 
As stated above, almost one half of overall healthcare costs is consumed by hospitals. According to Institute of Health Information and Statistics of the Czech Republic (2015), there were (as of 31 December 2015) 187 accredited hospitals in the Czech Republic, which is the lowest since 1994. See Figure 2.

Regarding hospital funding in the Czech Republic until 1991, there existed a system in which healthcare was financed from the state budget. In 1992, this system was replaced by another one, in which the healthcare was financed from health insurance. After that year, the hospitals were financed from public health insurance in form of payments for medical procedures. Hospitals received points based on their performance. The value of a point was dependant on the incomes and expenses of insurance companies. This unfortunately led to a hunt for points, needless prolongation of hospital treatment, and, moreover, to a lack of healthcare funding. From 1 January 1997, the Ministry of Health introduced a new list of medical procedures, according to which the value of a point became directly dependent on the Czech crown rate. In 2007, there was another fundamental change in the system and, as a result, the hospitals were financed in the form of the so-called lump sum payments. The amount of the lump sum payments was based on the assumption that the vast majority of hospital costs are fixed; that is, they are not dependent on the number of patients or the number of realised procedures. The amount of the lump sum payment was determined according to the actual costs from the previous year. On 1 January 2012, there came a crucial change in hospital funding. $75 \%$ of the hospital care then became financed through a system of payments for particular diagnostic groups, i.e., diagnosis related groups (DRG). The DRG system classifies groups of patients according to their diagnosis. Consequently, based on the estimated value of the average cost, the relative weight of each group is determined. This system has been in use since 1962. In the Czech Republic, it has been tested since 1996 and was comprehensively introduced in 2012 (Staňková, 2013). The development of consumption expenses of hospitals in the Czech Republic in absolute values (in mill. $\mathrm{CZK})$ and in \% of total costs of health insurance for medical care is given in Table 1. (Commentary: by 2005, IHIS was being used in their statistics the category of in-patient establishments, including institutes for long-term patients. Since 2006, there has been a separately listed category of hospitals.) As can be seen in the table, hospital costs have increased 2.5 times since 1999. However, in terms of percentage, they are still within the range of $44 \%-50 \%$.

Table 1 Development of the consumption expenses of hospitals in the Czech Republic in absolute values (in mill. CZK) and in \% of total costs of health insurance for medical care

\begin{tabular}{lcccccccc}
\hline & 1999 & 2000 & 2001 & 2002 & 2003 & 2004 & 2005 & 2006 \\
\hline Cost of hospitals & 41,159 & 41,420 & 44,818 & 48,638 & 67,909 & 72,238 & 76,542 & 74,424 \\
Total cost [\%] & 49.2 & 49.4 & 50 & 50 & 46.7 & 46.2 & 45.7 & 44.4 \\
\hline & 2007 & 2008 & 2009 & 2010 & 2011 & 2012 & 2013 \\
\hline Cost of hospitals & 81,917 & 89,370 & 96,548 & 102,932 & 103,982 & 104,674 & 103,998 \\
Total cost [\%] & 45.2 & 46.1 & 45.3 & 47.7 & 47.3 & 46.7 & 46.9 \\
\hline
\end{tabular}

Source: Institute of Health Information and Statistics of the Czech Republic (2000-2013) 
In past years, many hospitals in the Czech Republic went through the transformation from public to private ownership. The main milestone was the Act No. 290/2002 Coll., dealing with the transfer of certain other assets, rights and obligations of the Czech Republic to the competence of regions and districts, which entered into force on November 2003. Under this act, 82 district hospitals were passed into the competence of regions. These were gradually transformed into joint-stock companies. In 2009, there were 52 such hospitals in the Czech Republic. The proportion of private and public hospitals has therefore significantly changed since 1989. In 1992, there were only three private hospitals out of 183 . In 2000, 59 of 198 hospitals were privately owned. Currently, there are 78 private hospitals out of a total of 188 hospitals. By comparison, in Germany from 1991 to 2007, the share of all public hospitals has decreased from $46 \%$ to $32 \%$, whereas the share of all private hospitals has increased from $15 \%$ to $30 \%$ (Herr, 2008). According to Sloan (2000), the for-profit hospital is numerically in the minority in all developed countries.

The literature on hospital ownership addresses three fundamental questions. First, why do private not-for-profit organisations dominate the hospital industry? Second, how do private not-for-profits differ from for-profits in their behaviour? Third, is the private not-for-profit form more efficient in this industry?

\subsection{Private and public hospitals}

There are many studies about the efficiency of public and private hospitals - for example Ding (2014), Lacko et al. (2015), Herr (2008), Jehu-Appiah (2014) and Tiemann and Schreyögg (2009). According to Tiemann and Schreyögg (2012), there are a lot of studies about the ownership and quality of care, but only a few about the relationship between ownership, efficiency and quality.

In many studies, we can find that we have three different group of hospitals: public, non-profit and for-profit hospitals.

The literature on hospital ownership addresses three fundamental questions. First, why do private not-for-profit organisations dominate the hospital industry? Second, how do private not-for-profits differ from for-profits in their behaviour? Third, is the private not-for-profit form more efficient in this industry? (Sloan, 2000).

Most studies used for comparison of efficiency the date envelopment analysis (DEA) or stochastic frontier analysis (SFA). In general, SFA measures the technical aspect of cost efficiency and DEA mainly measures technical efficiency (Tiemann and Schreyögg, 2012). In fact, the authors use different techniques and data so the results can be different. For example, Barbetta et al. (2001) tested whether non-profit hospitals are more efficient than public ones. They get different results by the use of two different methodologies.

Some studies show that there is no clear difference between the private and public hospitals in efficiency (Sloan, 2000). In the USA, many studies show (Rosko, 2004; Folland and Hofler, 2001; Ozcan et al., 1992) that the investor-owned or private hospitals are less cost-efficient than the others. The study from Germany shows that public hospitals performed significantly better than their private for-profit and non-profit counterparts (Tiemann and Schreyögg, 2009). But the studies from Switzerland (Farsi and Filippini, 2008) show that there is no difference in efficiency according to ownership type. Lacko et al. (2015) proved that only one hospital after the transformation from public to private has better efficiency. 
In the literature, a number of studies can be found which deal with hospital efficiency; many are concerned with care quality and technical equipment. A large part of these studies takes into account heterogeneity of patients, i.e., case-mix index and also the hospital's characteristics (e.g., number of beds). Several studies focus on market characteristics (e.g., market competition). Table 2 shows a list of studies which discuss the relationship between hospital ownership and efficiency as well as their characteristics (Table 2). It can be observed that the authors have been discussing this topic for several decades, and yet this issue is still current.

Table 2 Empirical studies present the relationship between hospital ownership and efficiency

\begin{tabular}{lccc}
\hline Author & Covered region & Covered year & Covered hospitals \\
\hline Ozcan et al. (1992) & USA & 1987 & 3,000 \\
Burgess and Wilson (1996) & USA & 1988 & 2,246 \\
Mutter and Rosko (2007) & USA & $1999-2002$ & 869 \\
Daidone and D'Amico (2009) & Italy & $2001-2005$ & 108 \\
Barbetta et al. (2001) & Italy & $1995-1998$ & $\mathrm{x}$ \\
Jehu-Appiah et al. (2014) & Ghana & 2005 & 128 \\
Herr (2008) & Germany & $2001-2003$ & 1,500 \\
\hline
\end{tabular}

Source: Own survey

\section{Methodology and data}

This article, based on the research conducted at the university, focuses on the following research question:

Is there a difference between the efficiency of the hospitals in state and private ownership?

The main aim of this part of the research is to compare the efficiency of private hospitals and public hospitals, i.e., hospitals owned by the county, town or municipality, by the Ministry of Health, defence or of justice and by the church.

For this, the two-sample t-test for equal means om statistical program SPSS was used.

The formula for the pooled estimator of $\sigma^{2}$ is:

$$
S_{p}^{2}=\frac{\left(n_{1}-1\right) s_{1}^{2}+\left(n_{2}-1\right) s_{2}^{2}}{n_{1}+n_{2}-2}
$$

where $s_{1}$ and $s_{2}$ are the standard deviations of the two samples of hospitals and $n_{1}$ and $n_{2}$ are the sizes of the two samples of hospitals.

The formula for comparing the means of two populations using pooled variance is:

$$
t=\frac{\bar{x}_{1}-\bar{x}_{2}-\Delta}{\sqrt{s_{p}^{2}\left(\frac{1}{n_{1}}+\frac{1}{n_{2}}\right)}}
$$

where equation and equation are the means of the two samples, $\Delta$ is the hypothesised difference between the hospital means ( 0 if testing for equal means), $s_{p}^{2}$ is the pooled 
variance, and $n_{1}$ and $n_{2}$ are the sizes of the two samples. The number of degrees of freedom for the problem is:

$$
d f=n_{1}+n_{2}-2
$$

Because we looked for a difference between the groups in either, we used the two-tailed test, e.g., null hypothesis $\mathrm{H}_{0}$ is $\mu_{1}=\mu_{2}$ or $\mu_{1}-\mu_{2}=0$ and alternative hypothesis $\mathrm{H}_{\mathrm{A}}$ is $\mu_{1} \neq \mu_{2}$ or $\mu_{1}-\mu_{2} \neq 0$.

Research was carried out in November and December 2016. It was based on the latest available data obtained either from the information published on the website of the Institute of Health Information and Statistics of the Czech Republic (2015) or the annual reports of the individual hospitals, published on their websites. The research team focused on the following indicators:

a indicators of economic efficiency - operating profit for the year 2014 (or the last year available)

$\mathrm{b}$ indicators of non-economic efficiency - bed usage in days and average duration of stay.

The following hypotheses were defined:

$\mathrm{H} 1_{0}$ Economic efficiency measured by the indicator of operating profit is the same for state and private hospitals.

$\mathrm{H} 1_{0} \quad \mu_{1}-\mu_{2}=0$.

$\mathrm{H} 1_{\mathrm{A}}$ Economic efficiency measured by the indicator of operating profit differs for state and private hospitals.

$\mathrm{H} 1_{\mathrm{A}} \quad \mu_{1}-\mu_{2} \neq 0$.

$\mathrm{H} 2_{0} \quad$ Non-economic efficiency measured by the indicator of bed usage is the same for state and private hospitals.

$\mathrm{H} 2_{0} \quad \mu_{3}-\mu_{4}=0$.

$\mathrm{H} 2_{\mathrm{A}} \quad$ Non-economic efficiency measured by the indicator of bed usage differs for state and private hospitals.

$\mathrm{H} 2_{\mathrm{A}} \quad \mu_{3}-\mu_{4} \neq 0$.

$\mathrm{H}_{0} \quad$ Non-economic efficiency measured by the indicator of average treatment length is the same for the state and private hospitals.

$\mathrm{H} 3_{0} \quad \mu_{5}-\mu_{6}=0$.

$\mathrm{H} 3_{\mathrm{A}}$ Non-economic efficiency measured by the indicator of average treatment length differs for state and private hospitals.

$\mathrm{H} 3_{\mathrm{A}} \quad \mu_{5}-\mu_{6} \neq 0$.

\subsection{Determination of the research sample}

The specification of the research sample is the following: 
A research sample of 187 hospitals (a complete selection of all hospitals in the Czech Republic) was used in the evaluation process. The research focused on all three types of hospitals: university hospitals, which are defined by law in Act No. 372/2011 Sb. as government institutions funded by ministry departments. University hospitals provide healthcare services and undertake scientific research or development activities as well as provide facilities for education and clinical practice.

a Acute healthcare hospitals. In accordance with the Ministry of Health (Institute of Health Information and Statistics of the Czech Republic, 2000-2013), the average treatment time is no longer than 30 days in acute healthcare hospitals.

b Hospitals of subsequent care, which provide care for long-term patients who require treatment (on average above 30 days).

The actual situation in terms of owners of the hospitals in the Czech Republic is that $51 \%$ of the all hospitals in the Czech Republic are owned by the region, city or municipal administration, $41 \%$ of hospitals are owned by another legal entity, $5 \%$ remain the property of the Ministry of Health, $1 \%$ are owned by the church and $2 \%$ by the Ministry of Defense and Ministry of Justice (see other legal body) (see Table 3).

Table 3 Sample characteristics of the research

\begin{tabular}{llcc}
\hline Sample characteristics of the hospitals in the Czech Republic & Number & $\%$ \\
\hline $\begin{array}{l}\text { Typology of } \\
\text { the hospitals }\end{array}$ & University hospitals & 10 & 5 \\
& Acute healthcare hospitals & 146 & 78 \\
& Hospitals of subsequent care & 32 & 17 \\
Owner of the & Public owner - Ministry of Health & 10 & 5 \\
hospitals & Public owner - other legal body & 3 & 2 \\
& Public owner - region, city and municipal administration & 95 & 51 \\
& Public owner - church & 2 & 1 \\
& Private owner - other legal entity & 78 & 41 \\
\hline
\end{tabular}

Source: Own survey

\section{Results}

In our research we focused on the three following indicators:

a operating profit

b bed usage in days

c average duration of stay.

\subsection{Operating profit}

The statistical descriptive research sample of hospitals for operating profit is given in Table 4. 
Table 4 Group statistics description - operating profit in CZK

\begin{tabular}{|c|c|c|c|c|c|}
\hline & & Operating profit in & $C Z K$ & Statistic & Std. error \\
\hline \multirow{16}{*}{$\begin{array}{l}\text { Type of } \\
\text { hospital } \\
\text { ownership }\end{array}$} & \multirow{8}{*}{$\begin{array}{c}\text { Public } \\
\text { hospital }\end{array}$} & \multicolumn{2}{|c|}{ Mean } & $11,654,903.7943$ & $4,884,932.04064$ \\
\hline & & \multirow{2}{*}{$\begin{array}{l}95 \% \text { confidence } \\
\text { interval for mean }\end{array}$} & Lower bound & $1,959,665.9111$ & \\
\hline & & & Upper bound & $21,350,141.6775$ & \\
\hline & & \multicolumn{2}{|c|}{$5 \%$ trimmed mean } & $4,598,105.3950$ & \\
\hline & & \multicolumn{2}{|c|}{ Median } & $1,541,410.0000$ & \\
\hline & & \multicolumn{2}{|c|}{ Std. deviation } & $48,358,360.00204$ & \\
\hline & & \multicolumn{2}{|c|}{ Minimum } & $-39,295,000.00$ & \\
\hline & & \multicolumn{2}{|c|}{ Maximum } & $4,13 \mathrm{E}+8$ & \\
\hline & \multirow{8}{*}{$\begin{array}{l}\text { Private } \\
\text { hospital }\end{array}$} & \multicolumn{2}{|c|}{ Mean } & $9,661,421.7381$ & $4,373,552.29311$ \\
\hline & & \multirow{2}{*}{$\begin{array}{l}95 \% \text { confidence } \\
\text { interval for mean }\end{array}$} & Lower bound & $828,853.6958$ & \\
\hline & & & Upper bound & $18,493,989.7804$ & \\
\hline & & \multicolumn{2}{|c|}{$5 \%$ trimmed mean } & $6,874,262.2487$ & \\
\hline & & \multicolumn{2}{|c|}{ Median } & $6,078,000.0000$ & \\
\hline & & \multicolumn{2}{|c|}{ Std. deviation } & $28,343,858.34255$ & \\
\hline & & \multicolumn{2}{|c|}{ Minimum } & $-60,647,000.00$ & \\
\hline & & \multicolumn{2}{|c|}{ Maximum } & $1.61 \mathrm{E}+8$ & \\
\hline
\end{tabular}

Source: Own research

The two-sample t-test for equal means showed the following results (see Table 5). There are no significant differences in the operating profit between public and private hospitals. According to results of F-test we can not confirm the equal variances. Since the P-values are greater $(0.762)$ than the significance level $(0.05)$, we cannot reject the null hypothesis for this factor of effectiveness.

Table 5 T-test for equal means for operating profit of public and private hospitals

\begin{tabular}{|c|c|c|c|}
\hline & & \multicolumn{2}{|c|}{ Type of hospital } \\
\hline & & Equal variances assumed & $\begin{array}{l}\text { Equal variances } \\
\text { not assumed }\end{array}$ \\
\hline \multirow{2}{*}{$\begin{array}{l}\text { Levene's test for } \\
\text { equality of variances }\end{array}$} & $\mathrm{F}$ & 0.591 & \\
\hline & Sig. & 0.444 & \\
\hline \multirow{7}{*}{$\begin{array}{l}\text { T-test for equality of } \\
\text { means }\end{array}$} & $\mathrm{t}$ & 0.249 & 0.304 \\
\hline & df & 138 & 124.926 \\
\hline & Sig. (two-tailed) & 0.804 & 0.762 \\
\hline & Mean difference & $1,993,482.05619$ & $1,993,482.05619$ \\
\hline & Std. error difference & $8,001,772.14360$ & $6,556,715.69479$ \\
\hline & \multirow{2}{*}{$\begin{array}{l}95 \% \text { confidence interval } \\
\text { of the difference }\end{array}$} & Lower $-13,828,450.34585$ & $-10,983,146.88197$ \\
\hline & & Upper $\quad 17,815,414.45823$ & $14,970,110.99435$ \\
\hline
\end{tabular}

Source: Own research 


\subsection{Bed usage in days}

Table 6 presents the descriptive statistic representation of the hospital in the bed usage in days. As we can see, 95\% of bed usage (days) values are between 264 and 279 days by public hospitals. On the other hand, there is higher standard deviation by private hospitals and $95 \%$ of bed usage (days) values are between 242 and 280 days.

Table 6 Group statistics description - bed usage in days

\begin{tabular}{|c|c|c|c|c|c|}
\hline & & Bed usage in day & & Statistic & Std. error \\
\hline \multirow{16}{*}{$\begin{array}{l}\text { Type of } \\
\text { hospital } \\
\text { ownership }\end{array}$} & \multirow{8}{*}{$\begin{array}{l}\text { Public } \\
\text { hospital }\end{array}$} & \multicolumn{2}{|c|}{ Mean } & 271.1376 & 3.73037 \\
\hline & & \multirow{2}{*}{$\begin{array}{l}95 \% \text { confidence } \\
\text { interval for mean }\end{array}$} & Lower bound & 263.7477 & \\
\hline & & & Upper bound & 278.5274 & \\
\hline & & \multicolumn{2}{|c|}{$5 \%$ trimmed mean } & 270.2000 & \\
\hline & & \multicolumn{2}{|c|}{ Median } & 263.5000 & \\
\hline & & \multicolumn{2}{|c|}{ Std. deviation } & 40.00377 & \\
\hline & & \multicolumn{2}{|c|}{ Minimum } & 164.80 & \\
\hline & & \multicolumn{2}{|c|}{ Maximum } & 375.20 & \\
\hline & \multirow{8}{*}{$\begin{array}{l}\text { Private } \\
\text { hospital }\end{array}$} & \multicolumn{2}{|c|}{ Mean } & 260.9346 & 9.37112 \\
\hline & & \multirow{2}{*}{$\begin{array}{l}95 \% \text { confidence } \\
\text { interval for mean }\end{array}$} & Lower bound & 242.1213 & \\
\hline & & & Upper bound & 279.7479 & \\
\hline & & \multicolumn{2}{|c|}{$5 \%$ trimmed mean } & 264.5927 & \\
\hline & & \multicolumn{2}{|c|}{ Median } & 268.1500 & \\
\hline & & \multicolumn{2}{|c|}{ Std. deviation } & 67.57613 & \\
\hline & & \multicolumn{2}{|c|}{ Minimum } & 32.90 & \\
\hline & & \multicolumn{2}{|c|}{ Maximum } & 364.50 & \\
\hline
\end{tabular}

Source: Own research

Table $7 \quad$ T-test for equal means for bed usage in days in public and private hospitals

\begin{tabular}{|c|c|c|c|c|}
\hline & & & \multicolumn{2}{|c|}{ Type of hospital } \\
\hline & & & $\begin{array}{l}\text { Equal variances } \\
\text { assumed }\end{array}$ & $\begin{array}{l}\text { Equal variances } \\
\text { not assumed }\end{array}$ \\
\hline \multirow{2}{*}{$\begin{array}{l}\text { Levene's test for } \\
\text { equality of variances }\end{array}$} & $\mathrm{F}$ & & 17.351 & \\
\hline & Sig. & & 0.000 & \\
\hline \multirow{7}{*}{$\begin{array}{l}\text { T-test for equality of } \\
\text { means }\end{array}$} & $\mathrm{T}$ & & 1.217 & 1.012 \\
\hline & Df & & 165 & 67.683 \\
\hline & Sig. (two-tailed) & & 0.225 & 0.315 \\
\hline & Mean difference & & 10.20295 & 10.20295 \\
\hline & Std. error difference & & 8.38419 & 10.08631 \\
\hline & \multirow{2}{*}{$\begin{array}{l}95 \% \text { confidence interval } \\
\text { of the difference }\end{array}$} & Lower & -6.35118 & -9.92567 \\
\hline & & Upper & 26.75708 & 30.33157 \\
\hline
\end{tabular}

Source: Own research 
There are no significant differences in the bed used (days) between public and private hospitals. According to results of F-test we can confirm the equal variances. Since the P-values are greater $(0.225)$ than the significance level $(0.05)$, we cannot reject the null hypothesis for this factor of effectiveness.

\subsection{Average duration of stay}

The statistical descriptive research sample of hospitals for average duration of stay is given in Table 8.

Table 8 Group statistics description - average duration of stay in days

\begin{tabular}{|c|c|c|c|c|c|}
\hline & \multicolumn{3}{|c|}{ Average duration of stay in days } & Statistic & Std. error \\
\hline \multirow{16}{*}{$\begin{array}{l}\text { Type of } \\
\text { hospital } \\
\text { ownership }\end{array}$} & \multirow{8}{*}{$\begin{array}{l}\text { Public } \\
\text { hospital }\end{array}$} & \multicolumn{2}{|c|}{ Mean } & 15.3000 & 1.83152 \\
\hline & & \multirow{2}{*}{$\begin{array}{l}95 \% \text { confidence } \\
\text { interval for mean }\end{array}$} & Lower bound & 11.6718 & \\
\hline & & & Upper bound & 18.9282 & \\
\hline & & \multicolumn{2}{|c|}{$5 \%$ trimmed mean } & 12.3319 & \\
\hline & & \multicolumn{2}{|c|}{ Median } & 6.6000 & \\
\hline & & \multicolumn{2}{|c|}{ Std. deviation } & 19.64085 & \\
\hline & & \multicolumn{2}{|c|}{ Minimum } & 2.70 & \\
\hline & & \multicolumn{2}{|c|}{ Maximum } & 84.10 & \\
\hline & \multirow{8}{*}{$\begin{array}{l}\text { Private } \\
\text { hospital }\end{array}$} & \multicolumn{2}{|c|}{ Mean } & 31.1902 & 7.28549 \\
\hline & & \multirow{2}{*}{$\begin{array}{l}95 \% \text { confidence } \\
\text { interval for mean }\end{array}$} & Lower bound & 16.5569 & \\
\hline & & & Upper bound & 45.8235 & \\
\hline & & \multicolumn{2}{|c|}{$5 \%$ trimmed mean } & 22.9504 & \\
\hline & & \multicolumn{2}{|c|}{ Median } & 7.8000 & \\
\hline & & \multicolumn{2}{|c|}{ Std. deviation } & 52.02883 & \\
\hline & & \multicolumn{2}{|c|}{ Minimum } & 1.10 & \\
\hline & & \multicolumn{2}{|c|}{ Maximum } & 287.80 & \\
\hline
\end{tabular}

Source: Own research

Table 9 T-test for equal means for average duration of stay in public and private hospitals

\begin{tabular}{|c|c|c|c|c|}
\hline & & & \multicolumn{2}{|c|}{ Type of hospital } \\
\hline & & & $\begin{array}{l}\text { Equal variances } \\
\text { assumed }\end{array}$ & $\begin{array}{l}\text { Equal variances } \\
\text { not assumed }\end{array}$ \\
\hline \multirow{2}{*}{$\begin{array}{l}\text { Levene's test for } \\
\text { equality of variances }\end{array}$} & $\mathrm{F}$ & & 25.871 & \\
\hline & Sig. & & 0.000 & \\
\hline \multirow{7}{*}{$\begin{array}{l}\text { T-test for equality of } \\
\text { means }\end{array}$} & $\mathrm{T}$ & & -2.856 & -2.115 \\
\hline & Df & & 164 & 56.421 \\
\hline & Sig. (two-tailed) & & 0.005 & 0.039 \\
\hline & Mean difference & & -15.89020 & -15.89020 \\
\hline & Std. error difference & & 5.56315 & 7.51218 \\
\hline & \multirow{2}{*}{$\begin{array}{l}95 \% \text { confidence interval } \\
\text { of the difference }\end{array}$} & Lower & -26.87483 & -30.93643 \\
\hline & & Upper & -4.90556 & -0.84396 \\
\hline
\end{tabular}

Source: Own research 
There are no significant differences in duration of stay (days) between public and private hospitals. According to results of F-test we can confirm the equal variances. Since the Pvalues are lower (0.005) than the significance level (0.05). According to the research results, we can confirm that there are differences in effectiveness measured by the indicator 'average duration of stay' between public and private ownership.

\section{Discussion and conclusions}

A research study has focused on the comparison of private and public hospitals in the Czech Republic with a focus on the three factors of effectiveness - economic outcome, bed usage in days and the average duration of stay. These results can be compared also with the already published studies in various periodicals. According to the literature review conducted by the authors Sibbel and Nagarajah (2012), the issue of efficiency regarding private and other types of ownership are published in eight other studies which provide a closer analysis; three of these refer to the USA, three to Germany and one each to the Taiwanese and South Korean healthcare sectors. These studies compare private hospital operators with other types of ownership, where they differ considerably in their methodological approaches. Five studies reveal that public and not-for-profit hospitals are more efficient than those in private ownership. One study concludes the opposite, and two could not demonstrate any significant differences between different hospital ownerships. As mentioned above, the results of our study did not show any unequivocal difference in the efficiency of the hospitals in state and private ownership according to the selected indicators of efficiency. This difference was found only in relation to the indicator average duration of stay. If we evaluate the specific indicators, the results are following:

a Economic outcome - this indicator is maximalistic by its nature, i.e., the goal of the efficiency is to maximise its amount. From this perspective, it can be claimed that it is not relevant whether the hospital is public or private, as both privately owned hospitals and the hospitals in the public domain are loss-incurring. The arithmetic mean for the economic outcome is $11,654,904 \mathrm{CZK}$ for public hospitals and $9,661,422 \mathrm{CZK}$ for private hospitals.

b Bed usage in days - the aim of this indicator is to achieve maximum value as well. The maximum value assumes a value of 365 days, which is $100 \%$ of the bed usage during the year. There was no significant difference discovered between private and public hospitals. The arithmetic mean for bed usage in days is 271 days in public hospitals and 261 in private hospitals.

c Average duration of stay - the aim of the indicator is to minimise the duration of stay. This indicator is the only one that has shown a statistical difference between the private and public hospitals. The average duration of stay is approximately 15 days for public hospitals and approximately 31 days for private hospitals.

Of course, the limitations of the research need to be considered. Among the first to include is the limited veracity of the publicly available and published data on the indicators of hospital efficiency. In some cases, the hospitals must undergo a detailed examination of their financial situation. This is due to the allegations of misrepresentation of financial results. Other limitations of this study include the fact that it failed to obtain 
all the data for all hospitals in all measured indicators. Even so, the research results are very interesting and there is a potential for further research.

\section{References}

Barbetta, G.P., Turati, G. and Zago, A.M. (2001) On the Impact Of Ownership Structure and Hospital Efficiency in Italy, Universita Cattolica di Milano, Isitito di Economia Finanza, Mimeo, Milano.

Burgess Jr., J.F. and Wilson, P.W. (1996) 'Hospital ownership and technical inefficiency', Management Science, Vol. 42, No. 1, pp.110-123.

Daidone, S. and D'Amico, F. (2009) 'Technical efficiency, specialization and ownership form: evidences from a pooling of Italian hospitals', Journal of productivity Analysis, Vol. 32, No. 3, p.203.

Dana, L.P. (2000) 'The hare and the tortoise of former Czechoslovakia: small business in the Czech and Slovak Republics', European Business Review, Vol. 12, No. 6, pp.337-343.

Dana, L.P. (2010) When Economies Change Hands: a Survey of Entrepreneurship in the Emerging Markets of Europe from the Balkans to the Baltic States, Routledge, New York and Oxford.

Dana, L.P. and Ramadani, V. (2015) 'Context and uniqueness of transition economies', Family Businesses in Transition Economies, Springer, Cham.

Ding, D.X. (2014) 'The effect of experience, ownership and focus on productive efficiency: a longitudinal study of US hospitals', Journal of Operations Management, Vol. 32, No. 1, pp.1-14.

Farsi, M. and Filippini, M. (2008) 'Effects of ownership, subsidization and teaching activities on hospital costs in Switzerland', Health Economics, Vol. 17, No. 3, pp.335-350.

Folland, S.T. and Hofer, R.A. (2001) 'How reliable are hospital efficiency estimates? Exploiting the dual to homothetic production', Health Economics, Vol. 10, No. 8, pp.683-698.

Herr, A. (2008) 'Cost and technical efficiency of German hospitals: does ownership matter?', Health Economics, Vol. 17, No. 9, pp.1057-1071.

Herr, A., Schmitz, H. and Augurzky, B. (2011) 'Profit efficiency and ownership of German hospitals', Health Economics, Vol. 20, No. 6, pp.660-674.

Institute of Health Information and Statistics of the Czech Republic (2000-2013) Economic Information on Health Care [online] http://www.uzis.cz/katalog/zdravotnicka-statistika/ ekonomicke-informace-ve-zdravotnictvi (accessed 20 February 2017).

Institute of Health Information and Statistics of the Czech Republic (2015) Economic Results on Hospitals [online] http://www.uzis.cz/katalog/zdravotnicka-statistika/ekonomicke-vysledkynemocnic (accessed 15 February 2017).

Jehu-Appiah, C., Sekindde, S., Adjuik, M., Akazili, J., Almeida, S.D., Nyonator, F. and Kirigia, J.M. (2014) 'Ownership and technical efficiency of hospitals: evidence from Ghana using data envelopment analysis', Cost Effectiveness and Resource Allocation, Vol. 12, No. 1, p.9.

Keramidas, O. and Bout-Colonna, L. (2007) 'Public-private partnership: a new way of thinking for health management', International Journal of Public Sector Performance Management, Vol. 1, No. 1, pp.83-99.

Lacko, R., Hajduová, Z. and Andrejovský, P. (2015) 'Transformation of state-owned hospitals to private-owned: are selected hospitals more technical efficient?', Investment Management and Financial Innovations, Vol. 12, No. 4-si, pp.161-165.

Mutter, R.L. and Rosko, M.D. (2007) 'The impact of ownership on the cost-efficiency of US hospitals', Evaluating Hospital Policy and Performance: Contributions from Hospital Policy and Productivity Research, Emerald Group Publishing Limited, Bingley. 
National Health and Hospitals Reform Commission (2009) The Australian Health Care System: the Potential for Efficiency Gains - a Review of the Literature [online] http://onlinelibrary. wiley.com/doi/10.1002/hec.1622/full (accessed 20 February 2017).

Ozcan, Y.A., Luke, R.D. and Haksever, C. (1992) 'Ownership and organizational performance: a comparison of technical efficiency across hospital types', Medical Care, Vol. 30, No. 9, pp.781-794.

Rosko, M.D. (2004) 'Performance of US teaching hospitals: a panel analysis of cost inefficiency', Health Care Management Science, Vol. 7, No. 1, pp.7-16.

Sibbel, R. and Nagarajah, B. (2012) 'Are privately owned hospitals more efficient? Results of a survey of the international literature', Das Gesundheitswesen, Vol. 74, No. 6, pp.379-386.

Sloan, F.A. (2000) 'Not-for-profit ownership and hospital behavior', Handbook of Health Economics, Vol. 1, pp.1141-1174 [online] https://www.sciencedirect.com/science/article/pii/ S1574006400800347.

Staňková, P. (2013) Marketingové řizení nemocnic, Georg, Žilina.

Tiemann, O. and Schreyögg, J. (2012) 'Changes in hospital efficiency after privatization', Health Care Management Science, Vol. 15, No. 4, pp.310-326. 